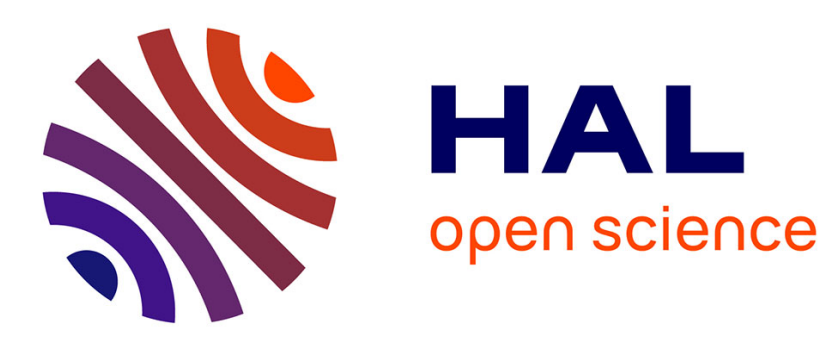

\title{
Parental wealth and resource transfers: How they matter in France for home ownership and living standards
}

Seymour Spilerman, François-Charles Wolff

\section{- To cite this version:}

Seymour Spilerman, François-Charles Wolff. Parental wealth and resource transfers: How they matter in France for home ownership and living standards. 2012. hal-00678988

\section{HAL Id: hal-00678988 \\ https://hal.science/hal-00678988}

Preprint submitted on 14 Mar 2012

HAL is a multi-disciplinary open access archive for the deposit and dissemination of scientific research documents, whether they are published or not. The documents may come from teaching and research institutions in France or abroad, or from public or private research centers.
L'archive ouverte pluridisciplinaire HAL, est destinée au dépôt et à la diffusion de documents scientifiques de niveau recherche, publiés ou non, émanant des établissements d'enseignement et de recherche français ou étrangers, des laboratoires publics ou privés. 
EA 4272

\title{
Parental wealth and resource transfers : How they matter in France for home ownership and living standards
}

\author{
Seymour Spilerman* \\ François-Charles Wolff**
}

$2012 / 10$

${ }^{*}$ Columbia University

**LEMNA - Université de Nantes et INED

Laboratoire d'Economie et de Management Nantes-Atlantique Université de Nantes

Chemin de la Censive du Tertre - BP 52231

44322 Nantes cedex 3 - France

www.univ-nantes.fr/iemn-iae/recherche

Tél. +33 (0)2 40141717 - Fax +33 (0)2 40141749 
PARENTAL WEALTH AND RESOURCE TRANSEERS: HOW THEY MATTER IN FRANCE FOR HOME OWNERSHIP AND LIVING STANDARDS*

\author{
Seymour Spilerman \\ Columbia University
}

Francois-Charles Wolff

Laboratoire d'Economie et de Management

Nantes Atlantique, University of Nantes and

Institut National d'Etudes Démographiques

August 2011

*We would like to thank Florencia Torche for her helpful comments on an earlier draft of this paper. 
The role played by parental wealth in facilitating the life chances and living standards of offspring is a topic of growing interest in stratification research. The addition of household wealth to the parental resource portfolio opens new issues with respect to mechanisms in the transmission of advantage across generations, since wealth transfers can take place at different points along the life course, in varying amounts, and for different purposes. This paper examines the impact of parental wealth and transfers of wealth on several aspects of the homeownership decision--the timing of the purchase, the cost of the home, and the downpayment proportion, as well as living standards subsequent to the purchase. We utilize a unique data set from France which contains information on parental wealth and wealth transfers from both sets of parents of a couple, as well as details on the timing of transfers in relation to a home purchase. The results make clear the complex pathways by which parental wealth influences the tenancy arrangements and living standards of offspring. 
PARENTAL WEALTH AND RESOURCE TRANSFERS: HOW THEY MATTER IN FRANCE FOR HOME OWNERSHIP AND LIVING STANDARDS

Seymour Spilerman
Columbia University
Francois-Charles Wolff

LEMNA, University of Nantes and INED

\section{INTRODUCTION}

The impact of parental resources on the life chances of offspring is a theme that has received much attention in the stratification literature. In early studies based on the socioeconomic attainment paradigm (e.g., Blau and Duncan 1967; Jencks, et. al. 1972) the outcome variables of primary interest were the occupational achievements and earnings of children, and the parental resources that were stressed were father's education and occupational status. In more recent investigations the array of resource items has been broadened to include both maternal characteristics and the assets of parents, and the range of outcome measures has similarly been extended to encompass a variety of aspects of the well-being of children (e.g., Conley 1999; Attias-Donfut 1995; Mayer 1997; Spilerman 2004).

Household wealth is probably the most significant addition to the parental resource portfolio. Inclusion of this asset has altered our imagery of the transfer process in two ways. First, it has heightened the emphasis on financial and material resources, in comparison with socialization effects. In the earlier formulations, in which parental education and occupational status were stressed, it was presumed that the main pathway by which parental resources exerted its influence on children's attainment was through the promotion of attitudes, values, and aspirations conducive to labor market success (Hauser 1971; Sewell and Shah 1968; Duncan, et. al. 1972), though the benefits of parental income and wealth were certainly appreciated (Henretta and Cambell 1978; Rumberger 1983). However, it was only with the formal expansion of the parental resource array that the role played by financial and material assets in the transmission of advantage could be explicitly modeled (Spilerman 2000).

Second, before the inclusion of parental wealth, when the intergenerational effects were sought in value transmissions, it was appropriate to 
associate parental resources with a respondent's teenage years, the period when socialization processes have their peak impact on children's decisions in regard to schooling and occupational choice. Indeed, this is the age point at which parental background characteristics were measured in the early studies of socioeconomic achievement ${ }^{1}$. However, a consideration of parental financial and material assets, and transfers of the assets, requires a recognition that the transmissions can take place at multiple points along the life course and in varying amounts. This opens issues of the timing of parental allocations, the sums transferred, and the intended purpose of the assistance--issues that do not arise when the parental resource array is limited to measures of educational attainment and occupational status. ${ }^{2}$

Transfers of parental wealth can influence the life chances and well-being of offspring in several ways: the transmissions can be targeted to enhance permanent income (e.g., investments in schooling; assistance with opening a business), support living standards (e.g., aid with the purchase of a home or an auto), insulate offspring from the financial trauma of job loss or illness, or the transfers can be used to build up the net worth of children. Parental wealth effects have been examined with regard to all these outcomes (e.g., Boehm and Schlottmann 2002; Torche and Spilerman 2006; McGarry and Schoeni 1995; Lindh and Ohlsonn 1998), though it is probably the case that the greatest attention has been given to the investigation of parental transfer effects on the home acquisition decision.

Home ownership is recognized as a significant factor in the economic well being of households. For working and middle class families housing equity is often the item of greatest value in their asset portfolio (e.g., Orzechowski and Sepielli [2003] on the US; Hamnett, et. al. [1991, chap 3] on England; Brandolini et. al. [2006] on Italy; Arrondel and Lefebvre [2001] on France).

${ }^{1}$ OCG I, the survey used by Blau and Duncan (1967) asked about parental characteristics when the respondent was age 16. This same age was also the reference point about parental status in the study by Featherman and Hauser (1978).

${ }^{2}$ A consideration of financial transfers also opens up matters of "backward flows" of resources from children to parents, and the possible interaction between public transfer programs and private family transfers. See AttiasDonfut (2003) and Kohli (1999) for discussions of these topics. 
Moreover, homeownership has served as a crucial vehicle in the buildup of household wealth (Belsky and Prakken 2004; Boehm and Schlottmann 2004), a consequence of the secular rise in home values in western countries since World War II, accentuated by the leveraged nature of a home purchase. Additionally, homeownership is treated favorably in the tax laws of many countries; see, for example, Bernardi and Poggio (2004) on Italy; Diamond and Lea (1992, chap. 3) on France. In the U.S., real estate taxes can be deducted from federal taxable income and there is an exclusion from taxes of $\$ 500,000$ from the profit of a home sale. Thus, while tenancy choice may reflect a life style preference rather than an investment calculation, families that selected homeownership have typically seen their net worth grow over the years. ${ }^{3}$

There are also externalities from home ownership that can enhance the life chances of children. Where parents own their residence, then, net of other background characteristics, the offspring have fewer behavioral problems (Haurin, et. al. 2002), are more likely to complete secondary education and undertake college study (Aronson 2000; Boehm and Schlottmann 1999), avoid public welfare in their adult years (Harkness and Newman 2003), abstain from having children while teenagers (Green and White 1997), and become homeowners themselves (Boehm and Schlottmann 2002; Kurz 2004; Pla and Cabrerizo 2004). While there are methodological problems with several of these studies, especially the failure to distinguish homeownership effects from pure wealth effects, the findings are consistent with other documented consequences of homeownership: greater residential stability and an interest in protecting property values, such as by surpressing neighborhood crime and ensuring quality schools (Lee et. al. 1994; Harkness and Newman 2002; Rossi and Weber 1996).

In light of these extensive effects of home ownership, the role played by parental resources in facilitating a home purchase has hardly been ignored by researchers. In particular, parental assistance has been found to reduce the waiting time from marriage to ownership--a finding that has been replicated in

\footnotetext{
${ }^{3}$ As of this writing, in mid 2009, the real estate crisis is in full bloom and housing prices are much depressed. Our analysis refers to the long time period from the end of World War II through early 2008. In the US, this period was characterized by a secular increase in home prices with only brief reversals in the trend. Whether or not home ownership will retain its status as a vehicle for equity buildup in the population remains to be seen.
} 
many western countries (e.g., Mulder and Wagner 1998 [West Germany and the Netherlands]; Kurz 2004 [West Germany]; Guiso and Jappelli 1999 [Italy]; LewinEpstein, et. al. 2004 [Israel\}; Mayer and Engelhardt 1996 [United States], thought not in some Latin American states (Torche and Spilerman 2006). Because the financial sums transferred can be considerable and because early entrance into homeownership provides a longer duration in which to accrue the economic returns from this tenancy status, several authors (e.g. Kurz 2004; Boehm and Schlottmann (2002) have come to view parental assistance with a home purchase as a critical vehicle in the transmission of parental wealth across the generational divide.

A limitation of this literature stems from the paucity of attention given to the alternative pathways by which parents can assist their children with the acquisition of a home. The availability of parental funds can affect a young couple's calculations in several ways: the transfers can be used to shorten the waiting time to homeownership, permit a larger downpayment, or enable a residence of greater value to be acquired. Only the first of these options has been the focus of sustained research--the literature noted in the prior paragraph--though some work has been done on the other pathways (e.g., Englehard and Mayer 1998; Gusio and Jappelli 1999).

Yet all three must be considered as they represent different routes by which parents contribute to the acquisition of a home and thereby to living standards; indeed, a focus solely on the waiting time will underestimate the magnitude of the full parental effect. In Chile, for example, parental resources have but a modest impact on the waiting time to ownership but strongly influence the value of an acquired residence (Torche and Spilerman 2006). Similarly, by facilitating a larger downpayment a parental transfer can reduce monthly mortgage costs, thereby permitting a higher level of non-housing consumption to be maintained (Engelhardt and Mayer 1998). In short, to understand the details of how parental assistance influences the home

\footnotetext{
${ }^{4}$ In Chile, and elsewhere in Latin America, there is much squatter tenancy, often on government owned land. In population surveys, respondents with such housing usually respond that they are homeowners though they lack legal title. See de soto (2000) on untitled assets in developing countries.
} 
acquisition process, it is necessary to consider the full panoply of uses of the parental funds, rather than restricting attention to a single component.

In the present study we use a unique data set from France, the Actifs Financiers Survey (Survey of Financial Assets) conducted by INSEE in 1991-92, which permits us to investigate the parental effects on each component of the home acquisition process. Moreover, with these data we can correct for the possible endogeneity of the parental transfers and model the joint determination of the downpayment proportion and the value of the home. That is, a purchaser may know, more or less, the total sum that will be available from parents and then decides how much to allocate to the downpayment, and how much to acquiring a more costly home. But this means that the error terms in the two outcome variables--downpayment proportion and home value--will be correlated and the estimation procedure should take this into account.

II. INSTITUTIONAL ARRANGEMENTS AND HOME OWNERSHIP IN FRANCE

The tenancy pattern and home ownership rate in a country are deeply influenced by governmental policies and by the generosity of financial supports available to builders, homeowners, and renters. Attempts to make sense of the diversity of housing policies in Europe have given rise to a number of typologies of housing systems, some based on Esping-Anderson's (1990) seminal classification of welfare states (e.g. Barlow and Duncan [1994]). Equally useful are typologies that derive from the structure of the housing market or from the housing statistics categories used by the individual countries.

Kemeny (2001) emphasizes the state's role in the organization of the rental market as a factor underlying the prevalence of the different tenancy types--co-residence with parents, market rental, public housing, and home ownership. Central to his scheme is the distinction between dual and unitary rental markets. In countries with a dual market system the state assumes responsibility for the provision of rental housing for poor families, separating this segment of the rental market from the private, profit-seeking sector. The result is a system with two distinct rental markets, one subsidized, the other 
demanding market prices. In contrast, in countries with a unitary rental market, access to public housing is not limited to poor families; rather, the profit-seeking sector must compete for tenants with the public sector. As a result, rents in the profit-seeking market are kept low, and the distinction between the two sectors is minimized.

Kemeny argues that the type of rental market system prevalent in a country bears strong implications for the home ownership rate. In the dualist system (e.g., England, U.S.), where all but the very poor confront high rents, the possibility of home ownership is an attractive alternative to renting. But in a unitary system (e.g., Germany, Denmark), where private sector rents are kept low by competition from public housing, rental tenancy is able to compete with home ownership. Data presented by Kemeny (2001, p. 67) for six European countries support his thesis: the countries characterized by a unitary system have considerably lower rates of home ownership. While France was not included in Kemeny's study, in terms of its rental policy (outlined below), it clearly falls into the unitary sector.

A variant classification of home ownership rates was suggested by Poggio (2006). Poggio speaks of "lands of tenure choice," where rental housing is available at a modest price so that the decision to own is made against reasonably priced rental alternatives (e.g., Germany); of "market-driven home ownership," where access to ownership is achieved mainly through commercial channels (e.g, United Kingdom); of the "social model" where the state is involved in the provision of home ownership (e.g., Norway); and of the "familisitic model," where ownership depends on the intergenerational transfer of parental homes (e.g., Italy). Poggio's first category bears a clear resemblance to Kemeny's unitary sector, and Poggio places France in this category. The special contribution of Poggio's typology lies in its clarification of the different state strategies with respect to facilitating home ownership.

A different sort of literature seeks to explain tenancy patterns and the home ownership rate by focusing on aspects of the credit market, often in a regression analysis framework (e.g., Chiuri and Jappelli [2000]; Scanlon and 
Whitehead [2004]). Here, the main attention is given to issues in the judicial enforcement of contracts, the socialization of business risk, and the structure of mortgage instruments. Chiuri and Jappelli (2000) rate 14 OECD countries on several of these measures; from their Table 2 it is evident that France is in the bottom third of countries in regard to efficiency of the judicial system and protections afforded to the mortgage lender ("rule of law"), and in the top third in terms of legal expenses of the lender in foreclosure proceedings. Scanlon and Whitehead (2004) examine the features of mortgage finance markets. In a comparison of 14 European countries (year 2000 data or thereabouts) France ranks second lowest in average loan-to-home value ratio (Scanlon and Whitehead 2004, Table 10). Also, the mortgage repayment period tends to be shorter in France than in most European countries, and the percentage of home owners holding a mortgage is the second lowest of the ten countries for which data were available (Scanlon and Whitehead 2004, Table 15). Thus, in France, home purchasers typically must make larger down payments and repay the loan in a short period; as a result, fewer mortgages are held. The summary picture from these comments is one of little state support for home ownership in France, either in the form of direct financial assistance to home buyers or in terms of risk mitigation for mortgage lenders. There is a robust program for the provision of social housing, but these efforts have focused on rental units (e.g. the programs of Habitat à Loyers Modérés). Even the limited funds for supporting home ownership have largely been allotted for the purchase of newly built structures, rather than more broadly available for the acquisition of existing homes (Miron 2001, p. 62). ${ }^{5}$

Not unexpectedly, given these considerations, the home ownership rate in France (56\%) in much below the average of the European countries (67\%)--Scanlon

\footnotetext{
5 There is a savings plan in France, intended to encourage home ownership, which permits the savings accumulations to be converted into low rate mortgages (Epargne-Logement). However, the mortgage loans in this program are not large and the minimum accumulation period is five years (18 months in a second type of account), precluding rapid entry into home ownership status. Complicating matters for a potential buyer, mortgages in France tend to be closely tied to the credit-worthiness of the borrower, with the loan amount capped so that annual payments do not exceed a third of household income (Miron [2001, p. 64]; Diamond and Lea [1992, pp. 55, 73; Table 3.3]).
} 
and Whitehead (2004, Table 2). More relevant for our purposes, the ownership rate by "young entrant households" is 17\% in France, in comparison with an average of 48\% for the other European countries (Scanlon and Whitehead [2004, Table 5]). While the definition of young entrant household is a bit complex, ${ }^{6}$ Chiuri and Jappelli (2000, Table 6) report analogous figures for household heads aged 25-29: an ownership rate of 20.4\% in France which is the second lowest among the 12 countries they surveyed.

In light of these matters we expect parental resources to play a considerable role in France in the home acquisition process. Young couples have little in the way of savings and, in the context of an inefficient mortgage market and few governmental supports for home ownership, the availability of parental aid can be a crucial factor. As noted, parental transfers can be used in several ways to assist with a home purchase; they can permit a reduction in the waiting time, facilitate the acquisition of a more costly home, or enable a higher downpayment thereby reducing carrying costs of the mortgage. Thus, to obtain a comprehensive picture of the impact of parental assistance on home ownership and living standards, we consider the parental effects on all three outcomes. Moreover, we examine both parental resource effects and transfer effects. While parental resources can serve as a proxy for transfers, in that parents with greater resources are likely to provide more assistance, the realized transfers do not necessarily encapsulate the full impact of parental resources. In particular, children who do not request assistance may nonetheless believe that they can overspend from their savings in the knowledge that, if required, parental aid will be forthcoming.

\section{THE HOUSEHOLD SURVEY AND ANALYTIC APPROACH}

The 1991-92 INSEE Survey of Financial Assets consists of a random sample of 9530 French households. The survey covers asset holdings of the respondent and transfer receipts from parents, as well as the usual biographical

\footnotetext{
${ }^{6}$ Young entrant household is defined in Scanlon and Whitehead (2004, p. 9) as a two-adult household without children, with the household head "around 25 years of age" and of average income for the age group.

7 Meron and Courgeau (2004) provide a comprehensive account of the issues facing young couples in France with respect to the transition to home ownership status, along with annual data on the rate of entry into home ownership.
} 
information about the respondent, spouse, and parents. The strengths of the survey, for our purposes, are that the background questions refer to both sets of parents of the couple and are sufficiently detailed to permit a crude wealth measure to be constructed for each parental household; moreover, the wealth questions pertain to when respondent and spouse were teenagers or young adults, permitting the parental resources to be associated with the startup expenses of a young couple. The precise questions ask about parental economic circumstance-father's occupation, parental asset holdings, financial difficulties--"when the respondent (spouse) was young." A disadvantage of the survey is that it is some 16 years old and does not capture the experiences of very recent entrants into the housing market. But this is offset by the unique coverage of the data-detailed information on the downpayment proportion, value of the home, and living standard of the couple, as well as details on parental wealth and the timing of transfers in relation to the purchase decision.

The survey has some limitations. It did not inquire about parental education, though information was gathered about father's occupation and this is a more proximate determinant of parental income. More consequential, the survey asks about the current residence of the respondent, not the first owned home. This is a serious matter since the literature relating home ownership to parental resources generally focuses on the first owned residence. However, in countries where entrance into home ownership is much delayed and, consequently, where fewer years remain in the life course for residence changes (e.g., Italy), there is a tradition of identifying a currently owned residence with the first acquired home (e.g., Guiso and Jappelli 1999; Bernardi and Poggio 2004). While such an identification is plausible for France in light of the aforementioned low ownership rate by "young entrants," our analysis does not rely on this assumption. Rather, in the main, we examine parental resource and transfer effects on features of the currently owned residence. Our imagery of the transfer effects is one of the accumulation of advantage, with the expectation that the financial benefits of parental assistance with a prior residence would likely be reflected in the value of the current residence. 
Several selection decisions were made. First, the sample was restricted to married or cohabitating couples without a prior marriage or children from an earlier union, and in which the respondent was less than 65 years old at the time of the survey. The limitation of no prior marriage is intended to reduce the complexity of having some couples who have had more than two sets of parents from whom transfers might have been received. The exclusion of respondents with children from a prior union removes problems of financial obligations due to an earlier cohabitation. The age restriction limits the sample to respondents who reached maturity post World War II. As a result of these decisions, the sample was reduced to 4,471 observations.

Our analysis is reported in two sections. In the first we examine parental resource effects on the waiting time to home ownership as well as on the ownership rate and the value of the home. The intent of this section is to assess the total effects of parental resources on the ownership decision, which includes the impact of anticipated transfers as well as realized transfers. The modeling strategy involves a consideration of the effects of the resources of husband's and wife's parents, followed by the introduction of terms for the human capital, income, and savings of the respondent's family. The logic of the strategy is that we first assess the total effects of parental resources on the dependent variables, then tease out the pathways by which the parental assets make their contribution--via direct transfers versus investments in education and in the earnings capacity of offspring.

In the second analytic section we restrict attention to homeowners and examine the effects of realized parental transfers on several outcome variables: the downpayment proportion, home value, and non-housing expenditures following a home purchase. In short, we seek here to understand the impact of transfers on the details of the home purchase decision as well as on subsequent living standards. Several methodological issues are taken into account. First, there is the potential endogeneity of transfers. Respondents who could not afford the downpayment might have requested help form parents, which would have been reported as a transfer. In this case, receipt of a transfer would be correlated with the error term, violating the regression assumptions. A second issue 
concerns the joint determination of downpayment proportion and home value: if parents have available a fixed sum to transfer, the allocations for the downpayment and for acquiring a more costly residence would be correlated. This possibility is also taken into account in the modeling.

\section{PARENTAL RESOURCE EFFECTS}

In this section we examine parental resource effects on the waiting time to home ownership and home value. The parental resources that are considered are father's occupational status (ISEI scores coded from two-digit occupational categories [Ganzeboom, et. al. 1992]) which is a proxy for permanent income, and parental wealth when the respondent "was young." The latter is an index created from the sum of three items: ownership of a home, other real estate, and a farm. Since working farms typically include a residence, respondents who reported that father was a farmer and owned both a farm and a home do not have farm ownership added to their sum. Admittedly, the resulting measure is a crude index of parental wealth; as a result, the true wealth effect will probably be underestimated. The parental resource variables also contain a measure of the financial well-being of the parental family when the respondent (spouse) was young--a dichotomous term, coded one if there were serious financial problems. Additionally, to tap demands on the parental resources, we added a term for the number of siblings of the respondent (spouse).

Measures of the couple's own resources include several human capital variables--household income, husband's and wife's education--and terms for accumulated savings as indexed by husband's age at marriage and duration of the union. Age at marriage is a proxy for savings prior to the union; individuals who are older at marriage have had more years to save. Similarly, duration of the marriage taps accumulations over the course of the union. Separate terms are introduced because the savings rate may differ before and after marriage; also, the latter captures the joint accumulations of husband and wife. Finally, we include dummy terms for city size and year of marriage; the first adjusts for location differences in the availability of rental housing that are correlated with city size, the second for temporal changes in government housing policy and 
mortgage availability. Descriptive statistics for these variables are reported in Table A-1.

Homeownership. Because of the limited resources of young couples and an inefficient mortgage market in France, the financial savings of parents are likely to play a considerable role in facilitating the acquisition of a home. As motivation for this investigation we present in Figure 1 survival curves of the waiting time from marriage to ownership of the current residence, with nonowners at the survey date treated as censored observations. The curves refer to different parental wealth levels; the top one shows the trajectory when neither set of parents had high wealth, the middle curve indicates the time path when one parental set, but not both, had high wealth, and the low curve pertains to couples in which both parental sets had high wealth. ${ }^{8}$ The effects of the extreme categories are consistent: at all time points the couples with low parental wealth are less likely to have made the transition to ownership status.

The path for respondents with one set of high wealth parents is intermediate for much of the time course though it overlaps with the high wealth curve at 18 years. These data, however, refer to the waiting time to a currently owned residence, and the likelihood that this residence is not the first owned home increases with marriage duration. Consequently, as a measure of the parental wealth effect on the waiting time to first owned home, the curves are most reliable for the early decades of marriage. For this period there is an evident tendency for the waiting time to be lessened when parental wealth is available, more so when there is wealth in the hands of both parental sets.

Figure 1 about here

Parental wealth is correlated with other parental characteristics, especially income and family size, which can also affect the availability of resources for transfer and thereby influence the waiting time. For this reason

\footnotetext{
${ }^{8}$ High wealth was defined as scores 2 or 3 on the wealth index. The resulting distribution contains 576 cases in which both parental sets had high wealth, 1,595 observations in which one but not both had high wealth, and 2,801 instances in which neither had high wealth.
} 
we report in column (1) of Table 1 a Cox model of the hazard to ownership, with regressors present for several measures of parental resources--father's occupational status, financial problems when respondent (spouse) was young, and number of siblings, as well as the wealth index. To allow for the possibility that assistance comes differentially from one side of the family, the resources are tabulated separately for each parental set. Also included, though not shown, are controls for city size and year of marriage to net out location and cohort effects.

Table 1 about here

The results are clear. Even in the context of terms for father's occupational status (a proxy for permanent income) and financial problems during youth, the wealth effects are considerable, of almost equal size for each parental set. Not surprisingly, the variable for number of siblings is negative for both parental sets, though significant only in the case of wife's parents; a larger sibship means that less assistance is available to each child. None of the other resource measures achieves significance.

While these findings are consistent with other studies of the impact of parental resources on the waiting time to ownership of a first home (e.g., Kurz 2004; Mulder and Smits 1999), we hesitate to follow Guiso and Jappelli (1999) or Bernardi and Poggio (2004) in associating a currently owned home with the first owned residence. Therefore, instead of further examination of the waiting time, we turn to a Probit model with the dichotomous variable, ownership of the current residence versus rental tenancy; this formulation does not require an identification of a currently owned residence with the first owned home. However, our argument about parental effects does assume that if the respondent owned a prior residence then the equity in that home, including the contribution from parental assistance, has been transferred to the current residence and not withdrawn from the housing market. In short, we presume that a respondent who owned previously has not moved into rental housing or traded down to a less 
expensive home; the latter process is important to our subsequent analysis of home value.

How reasonable are these assumptions? Trading down by homeowners does occur, but it mainly takes place among the elderly who are retired or contemplating retirement (Megbolugbe et. al 1997; Myers et. al. 1998). In regard to moves from ownership to rental housing, an examination of cohort data suggests that the ownership rate increases with age until the early or mid-60's (Banks and Rohwedder [2003] for the UK; Alessie and Kapteyn [2003] for the Netherlands; Borsch-Supan, et. al. [2003] for Germany; the last referencing real estate wealth). Thus, transitions out of home ownership, along with trading down, appear to be concentrated in the later stages of the life cycle.

We lack comparable data for France; however, there is no reason to expect a different pattern in that country. Further, we do have comparative country statistics on equity withdrawals from the housing market, a category that includes the renegotiation of existing mortgages and the contracting of second mortgages, as well as the preceding strategies for extracting housing market equity. These figures show that equity withdrawals in France (and Germany) are the lowest of the 10 European and North American countries that were surveyed (Catte, et. al. 2004, Figure 5b). Consequently, we consider the assumptions of a low rate of transition out of ownership status and a tendency by homeowners to transfer equity from a prior residence to the current one to be reasonable. It is these assumptions that provide the rationale for examining ownership status and home value of the current residence in terms of differences in parental resources.

The results from the Probit model, reported in column (2), are consistent with our contentions. The regressors in this equation are the same ones that appeared in the Cox model and the qualitative findings are quite similar: strong effects for the parental wealth terms but little evidence that other parental resources, aside from sibship size, are consequential as determinants of home ownership. We take the similarity in findings between the two models as evidence that for the great majority of respondents either the currently owned home is the first owned residence or that ownership tenure, once achieved, tends 
to be maintained, with the equity in an earlier residence transferred to the current one.

What, then, can be said about the pathways by which parental wealth contributes to ownership status? There are two routes of interest. First, parental resources can impact the savings accumulations of offspring through parental investments in schooling and earnings, with the cumulated household savings then applied to a home purchase. Second, direct transfers of parental wealth could be made available to children, to assist with the acquisition of a home.

These possibilities are explored in model (3), in which variables have been added for education of the respondent and spouse, household income, age of husband at marriage, marriage duration, and number in the household. The age and duration terms are proxies for household savings--older respondents would have had a greater opportunity to accumulate resources before marriage; in the same way, the duration variable indexes savings since marriage. Similarly, number in the household taps a possible desire by growing families to settle into home ownership and stabilize their housing arrangements. The empirical results provide strong evidence for the respondent's resource effects. The income variable and the proxies for household savings are all significant and have the expected signs. The term for marriage duration squared is negative, suggesting diminishing returns with savings growth; presumably, after a certain level of wealth accumulation the decision to become a homeowner is a lifestyle choice, not constrained by insufficient savings. The turning point, however, occurs at some 41 years of marriage, so the savings effect is positive over pretty much the full marital course.

Of particular relevance to understanding the transmission pathways concern the effects of the parental wealth terms. Even in the presence of the several measures of the respondent's savings and income, the wealth terms remain highly significant, reduced only modestly in size--husband's parental wealth remains at 87\% of its prior value; wife's parental wealth is $76 \%$ of its previous magnitude. Thus, while the resources of the respondent are hardly irrelevant to ownership prospects, the residual wealth effects suggest that direct financial assistance 
to children, rather than parental investments in human capital, is the dominant route by which parental wealth conditions housing tenure status.

Home value. If parental wealth influences the likelihood of ownership, what impact does it have on home value? This issue is addressed in Table 2 where the dependent variable refers to the value of the current home, as estimated by the respondent at the time of the survey. Because home value is a limited dependent variable--continuous for homeowners but zero for renters--we use a Tobit regression model. Also, to reduce skewness from a few large home values, we log this variable. Column (1) reports the total contributions of the parental resource terms, with controls present only for city size and marriage year. The results show that both father's occupational status and parental wealth have sizable impacts and that sibship size is negative, though significant only for wife's parental family. Not surprisingly, these effects indicate that home value is greater when the respondent and spouse come from families that have more wealth and income, the latter proxied by occupational status.

Table 2 about here

In column (2) we have added terms for respondent's economic status. These variables have effects similar to their contributions in the determination of homeownership: home value is greater when respondent and wife have higher household income and savings, the latter proxied by marriage duration and by age of husband at marriage. In the presence of these terms only the parental wealth variables remain significant. Again, the wealth terms are not much reduced-husband's father's wealth is $72 \%$ of its prior value, wife's father's wealth is 73\% of its former magnitude. These findings suggest that while parental occupational status (and earnings, by implication) affect home value through their impact on the incomes of offspring, parental wealth conditions home ownership through a different path, by facilitating direct financial transfers across the generations.

V. PARENTAL TRANSFER EFFECTS 
Having established that parental wealth has strong effects on the ownership rate of offspring and on home value, and that direct transfers are the principal route by which parental wealth exerts its impact, we turn to the ways by which the receipt of transfers, per se, influences the details of the home purchase decision. Specifically, we examine the consequences of parental transfers for the downpayment proportion, home value, and non-housing consumption, the latter viewed as a measure of living standards.

Whereas the previous analysis relied on the residual effects of parental wealth net of investments in the earning capacity of offspring to infer the role of parental transfers in the home acquisition process, we now examine the transfer effects directly. The transfers we assess include intervivos gifts and bequests, whether or not designated by parents as assistance intended for the purchase of a home.

The 1992 Actifs Financiers Survey contains information on both formal gifts signed before a notary and informal ones which are usually of smaller amounts. The gifts could have been money, land, or other valuables. We have detailed information for up to two gifts received by a respondent, with similar information for the spouse. For each gift we know the date and amount; also, when the transfer consisted of real property we have its value as estimated by the respondent. Two variables were created from this information--a dummy term for gift receipt, which takes the value one if assistance was received by respondent or spouse, and a term for gift value which is the sum of the individual gift amounts. Analogous information was collected for bequests, with comparable variables constructed. Since some transfers were received several years before a home purchase, all transfer amounts are capitalized at a $2 \%$ per year rate of return from the receipt date to the time of the purchase. Descriptive statistics for the variables used in this section of the paper are reported in Table $\mathrm{A}-2$.

A) Downpayment Proportion

One use of the transfer monies would be to increase the downpayment. A large downpayment means a lower monthly carrying cost; moreover, the mortgage interest rate itself might be reduced since the lender would be assuming less 
risk. In the INSEE survey, homeowners were asked about the downpayment proportion of the "most important home" they have purchased. In most cases, for reasons we have noted, the current dwelling is the only home that has been owned. However, in cases where a prior home was owned, the most significant residence might refer to that home.

We restrict attention in this analysis to the subsample of respondents who have ever purchased a home. An alternate approach would have been to retain renters in the sample and use a Heckman-type selection model (Kennedy 1998, p. 256), but we did not have a variable in the INSEE data set that could convincingly be used to identify the selection equation, namely a variable that affects the decision to acquire a home but does not have an impact on the downpayment proportion.

Figure 2 shows the distribution of the downpayment for several categories of gift/bequest amounts received before the home purchase. The entries make clear the close association between the downpayment proportion and the monetary value of a gift or bequest. At the low end of the distribution--downpayment below 10\%--households that did not receive a transfer predominate, and there is a clear downward progression in the representation rate of households as the transfer amount is increased. At the upper end--downpayment of more than 50\%-the findings are reversed: here there is a concentration of households that have received the largest transfers and an almost uniform increase in the representation rate with transfer amount.

Figure 2 about here

We next use a multivariate formulation to explore the impact of parental transfers on the downpayment proportion. Since the dependent variable is ordinal with six categories (downpayment $=0 \%$, less than $10 \%$ 10-30\%, 31-50\%, 5199\%, 100\%), we estimate an ordered Probit model,

$$
\begin{aligned}
& \mathrm{Y}_{\mathrm{i}}{ }^{*}=\boldsymbol{\beta}^{\prime} \mathrm{X}_{\mathrm{i}}+\boldsymbol{\varepsilon}_{\mathrm{i}} \\
& \mathrm{Y}_{\mathrm{i}}=\mathrm{k} \text { if } \mu_{\mathrm{k}-1}<\mathrm{Y}_{\mathrm{i}}^{*} \cdot \mu_{\mathrm{k}} \text { for } \mathrm{k}=1 \ldots 6,
\end{aligned}
$$


where $\mathrm{Y}_{i}^{*}$ is a latent variable, $\boldsymbol{\varepsilon}_{\mathrm{i}}$ follows a normal distribution, $\mathbf{x}_{\mathbf{i}}$ is a vector of covariates, and the cut points, $\mu_{1}$ through $\mu_{k-1}$, are estimated from the data. The observations in this analysis are the 3,271 respondents who purchased a home since marriage.

In Column (1) of Table 3 we report the effects of a gift or bequest receipt. Since the decision to acquire a residence might have been made in anticipation of a transfer, we have added dummy terms for gifts or bequests received subsequent to the purchase, as well as receipts prior to the purchase. We also include proxies for the savings and income of the household; thus, the parental transfer terms represent direct effects, net of a respondent's own resources. ${ }^{9}$ Husband's age, marriage duration in the purchase year, and number of persons in the dwelling serve as indicators of household savings; the last is a measure of demands upon the respondent's resources. Household income, in this analysis, is proxied by education and occupational status. Although income data are available in the INSEE survey they pertain to the survey year, while the purchase might have taken place decades earlier. For this reason, education and occupational status--relatively stable measures of permanent income--are utilized as indicators of household income at the time of the purchase.

Table 3 about here

The terms for respondent's resources are all significant in the regression. Husband's occupational status, education, and the proxies for household savings predict to a higher downpayment, while household size is inversely related to the downpayment proportion. Clearly, the ongoing costs of raising a large family mean fewer resources available for reducing the downpayment. In regard to the parental transfer terms, the receipt of gifts or bequests before a purchase increases the downpayment proportion, while transfers after the purchase date have no apparent effect. Thus, we fail to find evidence

\footnotetext{
${ }^{9}$ Also included in the regressions are controls for city size and year of the home purchase. The latter serves as a control for temporal variations in government policy that have affected access to credit.
} 
that, in making a decision about the downpayment, couples take into account the likelihood of a transfer receipt in the years subsequent to the home purchase.

A similar analysis was carried out with measures of the value of a gift or bequest, and the results, reported in column (2) reinforce the preceding account. The larger the gift or bequest received before a home purchase, the greater the downpayment. Thus, from these analyses of incidence and amount, we conclude that one mechanism by which parental transfers advantage offspring in the home acquisition process is to permit a higher downpayment, offsetting the monthly carrying costs of a mortgage. There is no evidence, however, that households take into account in their purchase planning the receipt of future transfers.

Endogeneity issues. There is a potential bias in the preceding account in that the parental transfers may be endogenous. This would occur, for example, if couples that cannot afford the downpayment turn to their parents for assistance. Conversely, it could be the case that parents are more likely to transfer funds to children who have chosen to make a large downpayment. In either case, receipt of a transfer would be correlated with the error term, violating the regression assumptions.

To address this issue we instrument the transfer variables on parental wealth. To secure identification we presume--not unreasonably--that transfers are the principal, if not the sole, channel by which parental wealth affects the downpayment proportion. A Probit model is used in the first stage regression when transfer incidence is addressed; a Tobit model is employed when transfer value is considered.

The second stage results are reported in Table 4. The models here are slightly different from those in Table 3 as it was necessary to combine gift and bequest receipts before a home purchase and delete the (non-significant) terms for transfer receipt after a purchase in order to have only one endogenous regressor in an equation. Otherwise, it would not have been possible to identify the multiple transfer terms. We present estimates from both the exogenous formulations of the transfer terms in columns (1) and (3) (which show the Table 3 results in condensed form) and the instrumented formulations in 
columns (2) and (4). In each case the instrumented values are higher, suggesting that the estimates from the exogenous model are downwardly biased and that the "true" contributions of parental transfers are somewhat greater.

Table 4 about here

B) Home Value

In addition to permitting a larger downpayment, parental transfers could be used to acquire a more expensive home. This possibility is explored in Table 5 using log(home value) as the dependent variable. We restrict the sample to homeowners because our key explanatory variables (transfer receipt before a home purchase; transfer receipt after a home purchase) are not defined for renters, and we use OLS regression. Further, because some of the models in this section require downpayment and home value information for the same residence, we take as observations only respondents who were home owners at the time of the survey and for whom we have matching downpayment data. The resulting sample contains 2,452 observations.

Table 5 about here

The explanatory variables are the ones described in reference to Table 3, except that household income is included as a regressor since both it and home value refer to the survey year. For the same reason, the marriage duration and age variables are computed at the survey year, not the home purchase year. Thus, we seek to examine the impact of parental transfers on current home value, net of the measures of respondent's household resources.

Several of the measures of respondent's resources are significant in column (1) which examines the impact of transfer incidence, and in column (2) which probes the contribution of transfer amount. Clearly, families that have higher incomes and greater savings (as indexed by marriage duration) tend to purchase more costly dwellings. Marriage, in contrast with cohabitation, is also associated with greater home value. Household size, however, has no effect. Whereas large families make a smaller downpayment (Table 3), suggesting 
financial constraints, there is no evidence of a similar impact on home value. Since the size of a residence is correlated with its value, large families might prefer to not reduce this home feature in their search for an appropriate dwelling .

The transfer terms reported in Table 5 indicate that, net of a respondent's own resources, households that have received gifts (though not bequests) before the purchase tend to own more costly homes. This is the case with respect to both transfer incidence and transfer amount. Again, consistent with the findings in Table 3 for downpayment proportion, the receipt of a transfer after the home purchase has no impact on home value. Clearly, the evidence for anticipation of a transfer affecting the expenditure decision is lacking.

Joint estimation model. Our findings to this point provide strong evidence that parental transfers influence both the downpayment proportion and the value of the acquired residence. But one issue of model specification remains to be explored. It may be the case that, reflecting their resources, parents make available a fixed sum for transfer and that the respondent then decides how much to apply to the downpayment and how much to the acquisition of a larger or an upscale residence. This imagery suggests that the two outcomes are jointly determined, in which case they should be modeled with a formulation that takes this fact into account.

The specific problem posed by jointly determined dependent variables is one of correlated errors. Separate estimation of each equation ignores the correlation and is inefficient. We address this issue with a joint model in which the downpayment proportion is estimated with an ordered Probit and home value with an OLS regression. ${ }^{10}$ Joint estimation of the equations was carried out using a maximum likelihood algorithm with numerical integration of the residuals from the statistical package aML (Lillard and Panis 2003). In order to achieve convergence the transfer variable combines gift and bequest amounts

${ }^{10}$ The joint model is similar to a SUR (Seemingly Unrelated Regression) formulation in the case of linear equations (Greene 1990, pp. 509-12). In our specification one of the equations is nonlinear, an ordered Probit. 
received before the home purchase in place of a separate consideration of the two transfer components.

Our findings are reported in Table 6. In the first two columns we present results for the downpayment proportion and for home value in which the equations were estimated separately. These are our baseline calculations from the condensed specification of the contributions of parental transfers to the two outcome variables. Column (3) reports the corresponding estimates from the joint model. While the results are not strikingly different, the estimates of the transfer terms tend to be higher; in both the downpayment equation and in the home value equation the increase is some 14\%. Moreover, the correlation between the residuals $(0.616)$ is significant, suggesting that unobserved factors have a similar influence on both outcomes. For example, parents who are greatly concerned about the financial welfare of their children might provide greater assistance for both a larger downpayment and a more expensive home.

Table 6 about here

Finally, what can be said about the quantitative effects of the parental transfers? By how much is the downpayment increased and by how much is the value of the home raised? Our data do not permit these issues to be addressed in terms of purchase price, only with respect to the value of the home at the survey date. Also, since the downpayment proportion is reported in six categories (see Figure 2), it must be transformed into a continuous distribution in order to estimate the change in proportion. We did so using an approach that is similar to the method of simulated residuals described in Gourieroux et. al. (1987).

The downpayment category midpoints provide a first approximation to a continuous distribution. The resulting measure, however, has its mass concentrated at six points and is not suitable as a dependent variable in a regression. Therefore, for each respondent we drew a random value from the uniform distribution,

$$
f(x)=1 /(b-a), \text { for } a<x<b \text {, }
$$


where [a,b] corresponds to the respondent's downpayment interval. This distribution has a mean equal to $(a+b) / 2$, which is, in fact, the midpoint of the category. The downpayment value assigned to a respondent is then the random draw that lies within his or her interval.

With this assignment, model (3) of Table 6 was reestimated, leading to the following assessment: For each 10,000 francs received from parents before the purchase, $^{11}$ home value (in 1992) was greater by 4,327 francs and the downpayment was increased by 0.72 percent. In terms of average home value in 1992, the latter amounts to an extra 1,293 francs in home equity. Admittedly, these are very rough estimates but they provide some sense of the contribution of a parental transfer to home equity.

C) Non-housing consumption

The parental transmissions that are intended to assist with the purchase of a home can have externalities that spill over to other aspects of living standards. Whether a transfer is used to increase the downpayment proportion or to offset the withdrawal from household savings in order to finance the purchase, there will be a lessening of the draw from a respondent's own resources to meet the ongoing mortgage costs and other expenses associated with home maintenance. The INSEE survey does not permit us to go into detail on these consequences of the parental transfers, but there is one item that provides a summary measure of the impact of the transfers on living standards. The survey asks whether a respondent's household has reduced its nonhousing consumption expenditures as a result of the home purchase, and we have tabulated the responses in terms of the gift/bequest amount received before the home purchase. The results, reported in Figure 3, provide evidence for the spill over of the parental transfers into other living standard domains. In particular, the response, "yes, we have reduced non-housing consumption" shows a consistent (though modest) decline with generosity of the transfer, and the response "no, we did not reduce consumption" shows an evident increase with

${ }^{11}$ To put this sum into perspective, the average gift before purchase was some 81,000 francs and the average bequest was 86,000 francs (see Table A-2). To translate these amounts into dollars, during the period 1970-1990 the franc varied from 4/dollar to 10/dollar. Thus, at a value of 6/dollar, a 10,000 franc transfer amounted to $\$ 1,667$. 
transfer amount. Indeed, some 49\% of respondents who received a large gift or bequest before the purchase reported no reduction in consumption, in contrast with 35\% who received no transfer. In short, there is clear evidence of a diffuse effect of the transfers on living standards, extending beyond their direct contribution to the home purchase decision.

Figure 3 about here

VI. CONCLUSIONS

While a number of studies have documented the impact of parental resources on home ownership, along with the effects of parental transfers on aspects of the ownership decision, the contribution of the present undertaking has been to investigate the linkages among these several factors. Specifically, using a unique data set from France, we have examined how parental resources, especially the wealth component, and parental transfers influence the details of the home acquisition process--the likelihood of ownership, the downpayment proportion, and home value--as well as the contribution of the parental assistance to a broad measure of living standards.

The results provide a consistent picture of the importance of parental wealth for the several outcome variables. Our index of parental wealth makes a significant contribution to the homeownership rate and to home value, effects that remain large even in the presence of controls for respondent's earnings and accumulated savings. This suggests that the mechanism through which parental wealth operates is one of direct transfers, rather than investments in the human capital of children. An examination of the details of the transfer process reveals that the parental assistance is used to both increase the downpayment proportion and raise the value of the acquired residence. Moreover, these effects are robust to modifications in the specification of the transfer process.

Yet, while this paper is nominally about the operation of the housing market, the deeper issues that motivated the study concern the role of parental wealth and financial transfers in the transmission of advantage across 
generations. We have focused on the housing market because for the majority of families in the US, as well as in France, home ownership is the asset of greatest value in their wealth portfolio. Further, the assistance provided by parents for a home purchase tends to involve sums that are considerable and thereby constitutes a major avenue in the transmission of material resources across generations. This is true for the US (Engelhardt and Mayer 1994; 1998; Boehm and Schlottmann 2002) as well as for France.

Parental wealth and intervivos transfers are understudied topics in stratification research, though see the recent important contributions by Conley (1999); Keister (2000; 2005), Wolff (2006), and Davies (2008). This oversight requires remedy because household wealth is a major item in the parental resource base, and because it is used by parents expediently to advantage the attainments and living standards of offspring. Also, since parental wealth is positively correlated with parental education and occupational status--the parental resources commonly studied--omission of the wealth variable means that the effects of the remaining terms may be biased upwards.

With respect to the imagery of the transmission process, the absence of a measure of parental wealth effectively removes "agency" from the parental domain--the use of transfers by parents to achieve particular goals, either for themselves or the child. Without a consideration of parental wealth and financial transfers, we cannot address parental decision making concerning when to transmit, how much to transfer, for what purposes and to which child, a motif that is critical to understanding the ways that parents contribute to the life chances and well-being of their offspring.

With the accelerating privatization of essential social services in recent decades, household wealth has become a critical resource, as families increasingly must self-insure against the risk of misfortune. This trend has amplified the importance of intergenerational financial linkages, as well. Young couples have a great many material needs associated with the start of a new family, while their incomes, relative to median household income, have been declining over the past 30 years (Mishel, et. al. 2009, pp. 55-56); this makes 
for a precarious financial situation and a heightened dependence on parental resources and parental assistance.

As a final matter, writing in mid-2009 one can hardly ignore the recent collapse in home prices. How might this economic downturn impact the role of homeownership as a vehicle in the buildup of household wealth through the accumulation of home equity? The downturn in home prices was abrupt and substantial--between 2006 and 2009 the Case-Schiller 20 city composite index of home prices fell by 30\% (Marketwatch 2009). However, this decline has brought prices back only to 2003 levels, and families that purchased as recently as the year 2000 are still ahead, on average, by some 28\%, as well as having enjoyed the tax benefits associated with homeownership.

While buyers of homes in very recent years have been severely harmed by the price decline--and this has disproportionately impacted young couples--the acquisition of a residence is a long term investment and, going forward, it is not clear that this will fail to be a sound investment. Indeed, in the immediate future, following the steep price decline, a home purchase might be a wise move by a young couple. Yet, what is fairly certain to ensue in the wake of the steep price decline is that mortgage lenders will be more circumspect about the credit worthiness of new home buyers and will require a larger downpayment from them to reduce the risk of default. This, in turn, will mean an even greater reliance on parental assistance in order to purchase a residence. 


\section{BIBLIOGRAPHY}

Alessie, Rob and Arie Kapteyn. 2003. "Savings and Pensions in the Netherlands." Chapter 6 in Axel Borsch-Supan (ed.). Life-Cycle Savings and Public Policy. New York: Academic Press.

Aronson, D. 2000. "A Note on the Benefits of Home Ownership." Journal of Urban Economics 47 , pp. 356-69.

Arrondel, L. and B. Lefebvre. 2001. "Consumption and Investment Motives in Housing Wealth Accumulation: A French Study." Journal of Urban Economics 50. Pp. 112-37.

Attias-Donfut, C. 1995. Les Solidarites Entre Generations: Vieillesse, Familles, Etat. Paris: Nathan.

Attias-Donfut, Claudine. 2003. "Family Transfers and Cultural Transmissions Between Three Generations in France." Chapter 11 in Vern L. Bengtson and Ariela Lowenstein (eds.). Global Aging and Challenges to Families. New York: Aldine.

Banks, James and Susann Rohwedder. 2003. "Pensions and Live-Cycle Savings Profiles in the UK." Chapter 7 in Axel Borsch-Supan (ed.). Life-Cycle Savings and Public Policy. New York: Academic Press.

Barlow, J. and S. Duncan. 1994. Success and Failure in Housing Provision. Oxford: Elsevier.

Belsky, Eric and Joel Prakken (2004). "Housing Wealth Effects: Housing's Impact on Wealth Accumulation, Wealth Distribution, and Consumer Spending." Joint Center for Housing Studies, Harvard University. Working Paper W04-13.

Bernardi and Poggio 2004. "Home-Ownership and Social Inequality in Italy." Chapter 8 in Karen Kurz and Hans-Peter Blossfeld (eds.). Home Ownership and Social Inequality in Comparative Perspective. Stanford: Stanford University Press.

Bernardi, Fabrizio and Teresio Poggio. 2004. "Home Ownership and Social Inequality in Italy." Chapter 8 in Karen Kurz and Hans-Peter Blossfeld (eds.). Home Ownership and Social Inequality in Comparative Perspective. Stanford: Stanford University Press.

Blau, Peter and Otis D. Duncan. 1967. The American Occupational Structure. New York: Wiley.

Boehm, T. and A. Schlottmann. 2002. "Housing and Wealth Accumulation: Intergenerational Impacts" Chapter 14 in Retsinas, Nicholas and Eric 
Belsky (eds.), Low-Income Homeownership: Examining the Unexamined Goal. Torche and Spilerman 2006

Boehm, Thomas P. and Schlottmann, Alan M. 1999. "Does Home Ownership by Parents Have an Economics Impact on Their Children?" Journal of Housing Economics 8. Pp. 217-232.

Boehm, Thomas P. and Schlottmann, Alan M. 2004. Wealth Accumulation and Homeownership: Evidence for Low-Income Households. Washington: US Department of Houseing and Urban Development.

Borsch-Supan, Axel, Anette Reil-Held, and Reinhold Schnabel. 2003. "Household Saving in Germany." Chapter 3 in Axel Borsch-Supan (ed.). Life-Cycle Savings and Public Policy. New York: Academic Press.

Brandolini, Andrea, Luigi Cannari, Giovanni D'Alessio and Ivan Faiella. 2006. "Household Wealth in Italy in the 1990s." Chapter 7 in Edward N. Wolff (ed.), International Perspectives on Household Wealth. Cheltenham, UK: Edward Elgar.

Catte, Pietro, Nathalie Girouard, Robert Price, and Christophe Andre. 2004. "Housing Markets, Wealth and the Business Cycle", OECD Economics Department Working Papers, No. 394. Paris: OECD Publishing.

Chiuri, Maria C. and Tullio Jappelli. 2000. "Financial Market Imperfections and Home Ownership: A Comparative Study." Center for Studies in Economics and Finance (CSEF). Working Paper No. 44 (December).

Conley, Dalton. 1999. Being Black, Living in the Red: Race, Wealth, and Social Policy in America. Berkeley: University of California Press.

Davies, James B. (ed.) 2008. Personal Wealth from a Global Perspective. Oxford: Oxford University Press.

De Soto, Hernando. 2000. The Mystery of Capital New York: Basic Books.

Diamond Jr., Douglas B. and Michael J. Lea. 1992. "Housing Finance in Developed Countries: France" Journal of Housing Research 3 (1), pp. 39-77.

Duncan, Otis D., Featherman, David, and Beverly Duncan. 1972. Socioeconomic Background and Achievement. New York: Seminar Press.

Engelhardt, Gary and Christopher Mayer. 1994. "Gifts for Home Purchase and Housing Market Behavior." New England Economic Review. May-June, pp. 4758 .

Englehard, Gary V. and Christopher J. Mayer. 1998. "Intergenerational Transfers, Borrowing Constraints, and Saving Behavior: Evidence from the Housing Market." Journal of Urban Economics 44, pp. 135-57.

Esping-Andersen, Gosta. 1990. The Three Worlds of Welfare Capitalism. Princeton: Princeton University Press.

Featherman, David L. and Robert M. Hauser. 1978. Opportunity and Change. New York: Academic Press.

Ganzeboom, H., P. de Graaf and D. Treiman. 1992. "A Standard International Socio-Economic Index of Occupational Status". Social Science Research 21: $1-56$.

Gourieroux, Christian, Alain Monfort, Eric Renault, and Alain Trognon. "Simulated Residuals." Journal of Econometrics 34, pp. 201-52. 
Green, Richard and Michelle White. 1997. "Measuring the Benefits of Homeownership: Effects on Children." Journal of Urban Economics. 41, pp. $441-461$.

Greene, William H. 1990. Econometric Analysis. New York: Macmillan

Guiso, L. and T. Jappelli 1999. "Private transfers, borrowing constraints and the timing of homeownership." Center for Studies in Economics and Finance. University of Salerno. Unpublished manuscript.

Hamnett, C., Harmer, M., and Peter Williams. 1991. Safe as Houses: Housing Inheritance in Britain. London: Paul Chapman.

Harkness, Joseph and Sandra J. 2003. "Differential Effects of Homeownership on Children from Higher and Lower Income Families." Journal of Housing Research 14, pp. 1-19.

Harkness, Joseph and Sandra J. Newman. 2002. "Homeownership for the Poor in Distressed Neighborhoods: Does this make Sense?" Housing Policy Debate 13 (3), pp. 597-630.

Haurin, Donald, Toby Parcel, and R. Jean Haurin. 2002. "Impact of Homeownership on Child Outcomes." Chapter 15 in Nicolas P. Retsinas and Eric Belsky (eds.) Low Income Homeownership. Washington: Brookings.

Hauser, Robert M. 1971. Socioeconomic Background and Educational Performance. Washington D.C.: American Sociological Association.

Henretta, J. and R. Campbell. 1978. "Net Worth as an Aspect of Status." American Journal of Sociology (83), pp. 1204-23.

Jencks, Christopher, Marshall Smith, Henry Acland, Mary Jo Bane, David Cohen, Herbert Gintis, Barbara Heyns, and Stephen Michelson. 1972. Inequality: A Reassessment of the Effect of Family and Schooling in America. New York: Basic Books.

Keister, Lisa. 2000. Wealth in America: Trends in Wealth Inequality. New York: Cambridge University Press.

Keister, Lisa. 2005. Getting Rich. Cambridge University Press.

Kemeny, Jim. 2001. "Comparative Housing and Welfare: Theorising the Relationship." Journal of Housing and the Built Environment 16. Pp. 53-70.

Kohli, Martin. 1999. "Private and Public Transfers Between Generations: Linking the Family and the State." European Sociological Review (1): pp. 81-104.

Kurz, Karen. 2004. "Labor Market Position, Intergenerational Transfers and Homeownership: A Longitudinal Analysis for West German Birth Cohorts." European Sociological Review 20 (2), pp. 141-59.

Lee, Barrett, R. S. Oropesa and James Kanan. 1994. "Neighborhood Context and Residential Mobility. Demography 31 (2), pp. 249-70.

Lewin-Epstein, Noah, Irit Adler, and Moshe Semyonov. 2004. Chap 13 in Karen Kurz and Hans-Peter Blossfeld (eds.). Home Ownership and Social Inequality in Comparative Perspective. Stanford: Stanford University Press.

Lillard, Lee A. and Constantijn W. A. Panis. 2003. aML Multilevel Multiprocess Statistical Software: User's Guide and Reference Manual, Verson 2. Los Angeles: Econware.

Lindh, Thomas and Henry Ohlsson. 1998. "Self Employment and Wealth Inequality." Review of Income and Wealth (44), pp. 25-42. 
Marketwatch. 2009. "Peak Recoil." Sept 18, 2009. www.marketwatch.com/story/atleast-home-prices-arent-the-Nasdaq-2009-09-18.

Mayer, Christopher J. and Gary V. Engelhardt. 1996. "Gifts, Down Payments, and Housing Affordability." Journal of Housing Research 7(1), pp. 59-77.

Mayer, Susan. 1997. What Money Can't Buy: Family Income and Children's Life Chances. Cambridge: Harvard University Press.

McGarry, Kathleen and Robert F. Schoeni. "Transfer Behavior in the Health and Retirement Study." Journal of Human Resources (30-Supplement). 1995. Pp. S184-S226.

Megbolugbe, Isaac, Jarjisu Sa-Aadu and James Shilling. 1997. "Oh, Yes, the Elderliy will Reduce Housing Equity under the Right Circumstances." Journal of Housing Research 8 (1), pp. 53-74.

Meron, Monique and Daniel Courgeau. 2004. "Home Ownership and Social Inequality in France." Chapter 3 in Karen Kurz and Hans-Peter Blossfeld (eds.). Home Ownership and Social Inequality in Comparative Perspective. Stanford: Stanford University Press.

Miron, John R. 2001. "Methods Used Abroad to Support Access to Homeownership: A Research Survey." Final Report submitted to the Canada Mortgage and Housing Corporation, July.

Mishel, Lawrence, Jared Bernstein and Heidi Shierholz. 2009. The State of Working America, 2008-9. Ithica: Cornell University Press.

Mulder, C.H. and J. Smits. 1999. "First-Time Home-Ownership of Couples: The Effect of Intergenerational Transmission." European Sociological Review $15: 323-337$.

Mulder, Clara H. and M. Wagner. 1998. "First Time Home-Ownership in the Family Life Course: A West German-Dutch Comparison." Urban Studies 35, pp. 687713 .

Myers, Dowell, Isaac Megbolugbe and Seong W. Lee. 1998. "Cohort Estimation of Homeownership Attainment among Native-Born and Immigrant Populations." Journal of Housing Research 9 (2), pp. 237-69.

Orzechowski, S. and P. Sepielli. 2003. "Net Worth and Asset Ownership of Households: 1998 and 2000." Current Population Reports, P70-88. Washington, DC: U.S. Census Bureau.

Pla, Anna C. and Juan A. M. Cabrerizo. 2004. "Home Ownership and Social Inequality in Spain." Chapter 9 in Karen Kurz and Hans-Peter Blossfeld (eds.). Home Ownership and Social Inequality in Comparative Perspective. Stanford: Stanford University Press.

Poggio, Teresio. 2006. "Different Patterns of Home Ownership in Europe." Paper presented at conference, "Home Ownership in Europe: Policy and Research Issues," Delft, Netherlands, November 23-24 2006.

Rossi, Peter H. and Eleanor Weber. 1996. "The Social Benefits of Homeownership: Empirical Evidence from National Surveys." Housing Policy Debate 7 (1), pp. $1-35$.

Rumberger, R. 1983. "The Influence of Family Background on Education, Earnings and Wealth." Social Forces 61:755-73.

Scanlon, Kathleen and Christine Whitehead. 2004. International Trends in Housing Tenure and Mortgage Finance. London: Council of Mortgage Lenders. 
Sewell, Wiliam H. and V. Shah. 1968. "Social Class, Parental Encouragement and Educational Aspirations." American Journal of Sociology 73, pp. 559-72.

Spilerman, Seymour. 2000. "Wealth and Stratification Processes." Annual Review of Sociology. Palo Alto: Annual Reviews.

Spilerman, Seymour. 2004. "The Impact of Parental Wealth on Early Living Standards in Israel." American Journal of Sociology 110 (1) July. Pp. $92-122$

Torche, Florencia and Seymour Spilerman. 2006. "Parental Wealth Effects on Living Standards and Asset Holdings: Results from Chile." Chapter 10 in Edward N. Wolff (ed.). International Perspectives on Household Wealth. Cheltenham: Edward Elgar.

Wolff, Edward N. (ed.). 2006. International Perspectives on Household Wealth. Cheltenham: Edward Elgar. 
Figure 1. Transition to Home Ownership, by Parental Wealth Category ${ }^{1}$

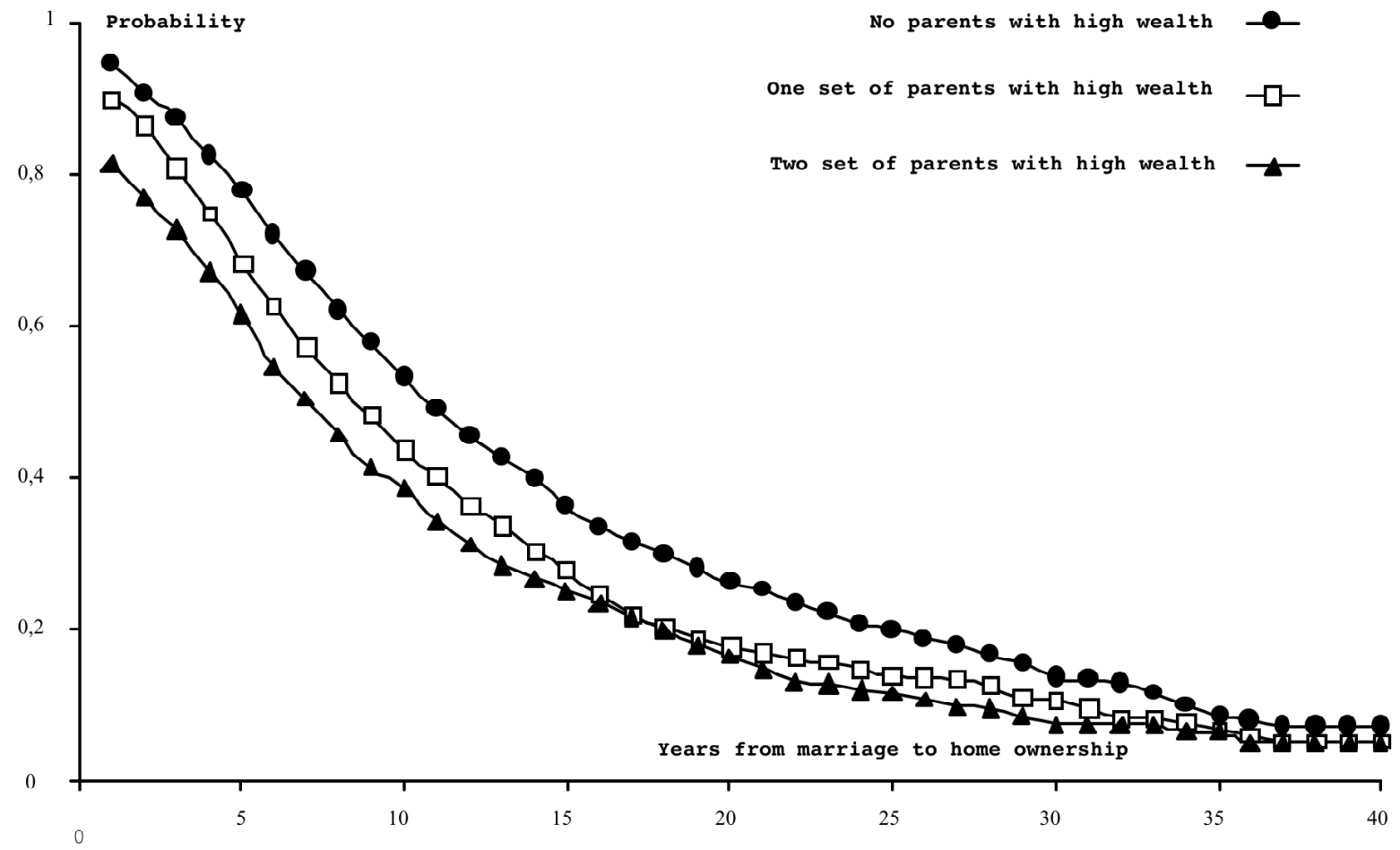

Source: Survey Actifs Financiers 1992.

1. Curves depict survival in the state of non-ownership. $\mathrm{N}$ (no parents) $=2,801$; $\mathrm{N}$ (one parental set $)=1,595 ; \mathrm{N}$ (two parental sets $)=576$. 
Figure 2. The Effect of Transfer Amount Received Before Home Purchase on Down Payment Proportion

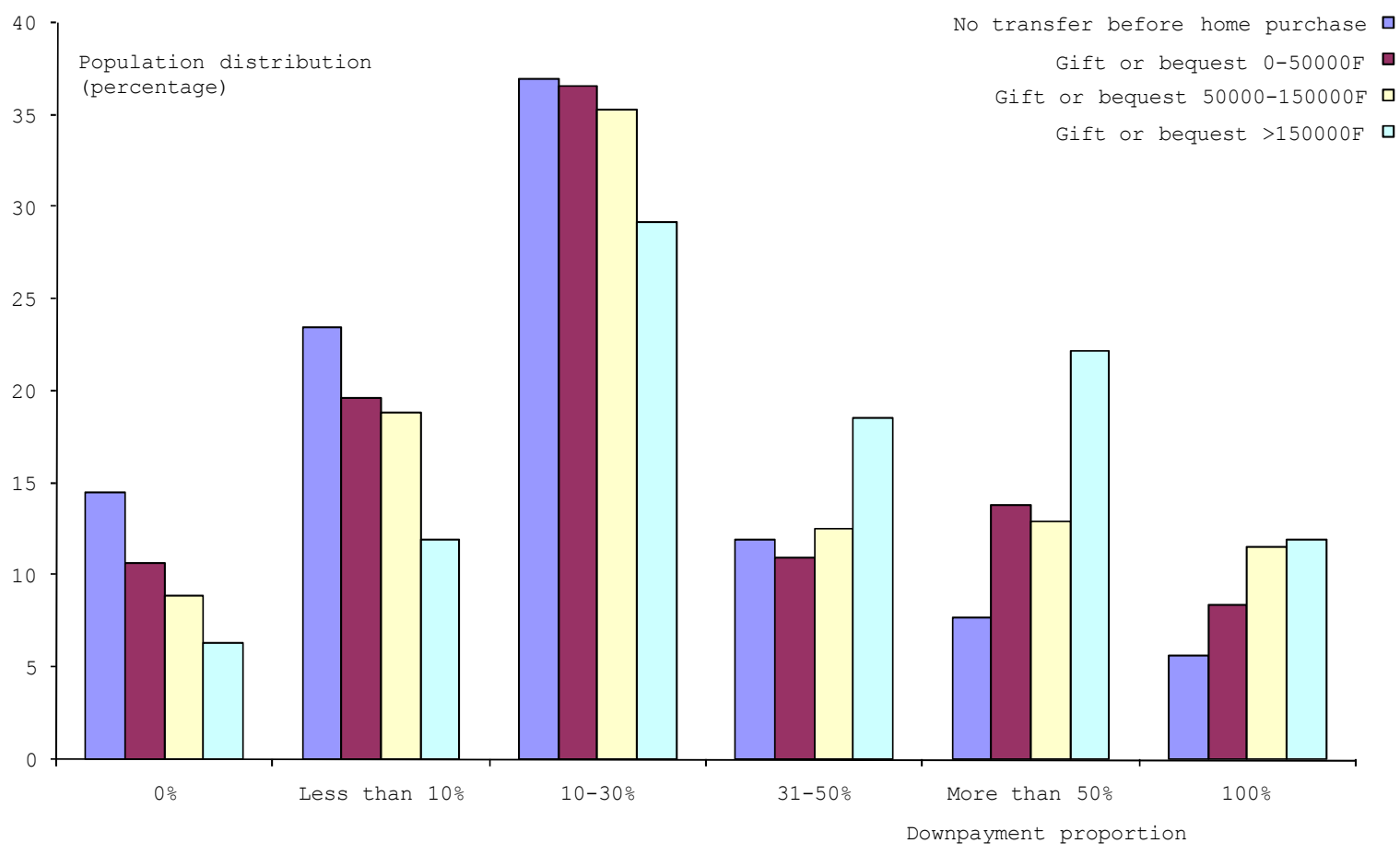

Source: Survey Actifs Financiers 1992. N = 3,271. 
Figure 3. Reduction in Non-Housing Consumption Following the Home Purchase, by Transfer Amount ${ }^{1}$

No transfer before home purchase

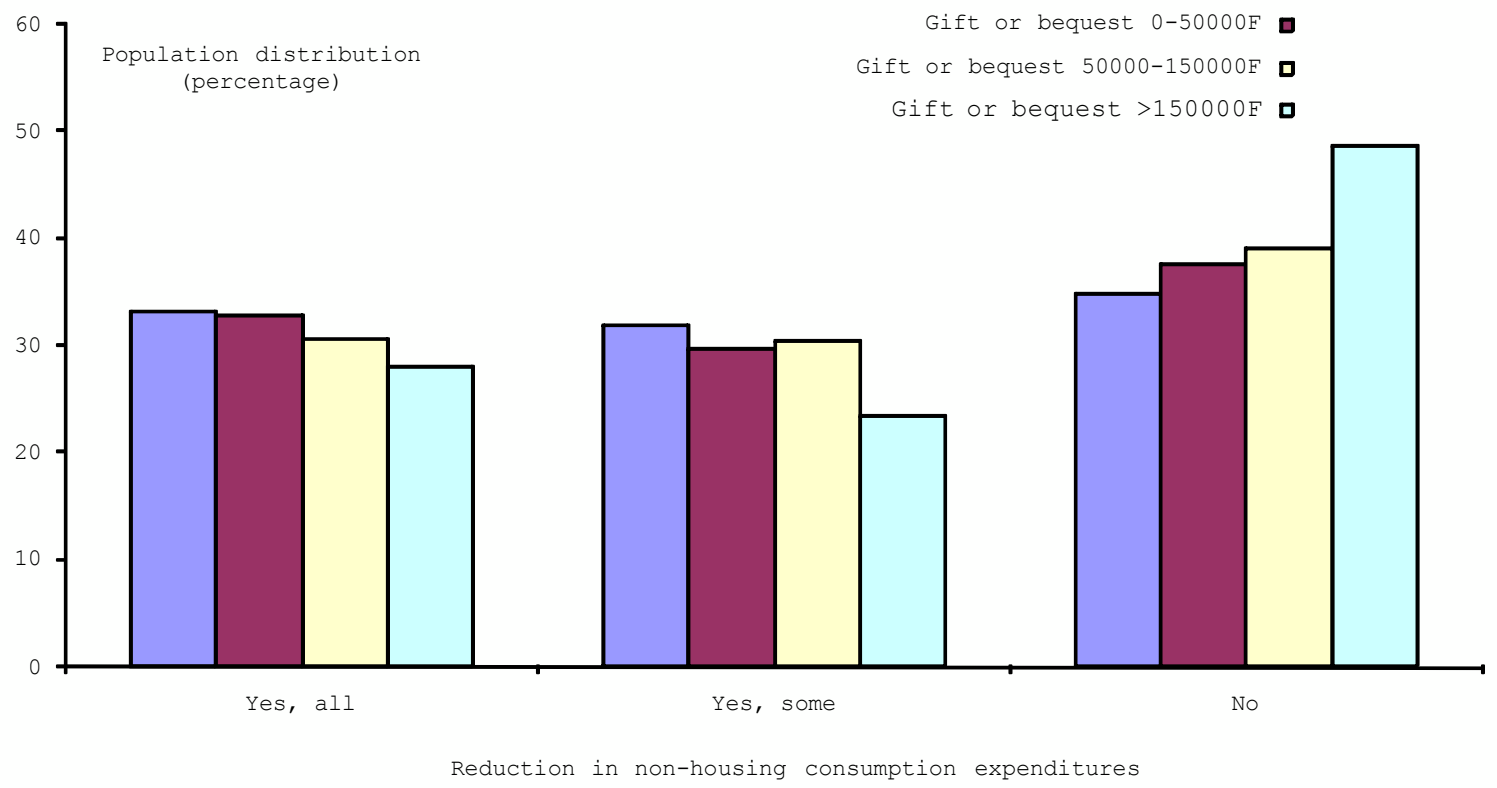

Source: Survey Actifs Financiers 1992.

1. Response to question: Has your household reduced its non-housing consumption expenditures because of the home purchase? $\mathrm{N}=3271$. 
Table 1. Parental Resource Effects on Hazard of Homeownership and Home Ownership Rate

\begin{tabular}{|c|c|c|c|c|c|c|}
\hline \multirow[t]{2}{*}{ Variables $^{2}$} & \multirow{2}{*}{\begin{tabular}{l|l} 
(1) Cox \\
coef
\end{tabular}} & \multirow{2}{*}{$\begin{array}{l}\text { Model } \\
\text { t-value }\end{array}$} & \multicolumn{2}{|c|}{ (2) Probit Model } & \multicolumn{2}{|c|}{ (3) Probit Model } \\
\hline & & & coef & $\underline{t \text {-value }}$ & $\underline{\text { coef }}$ & t-value \\
\hline Constant & & & $1.058 * \star$ & $(9.72)$ & $-7.241 \star \star$ & $(11.69)$ \\
\hline \multicolumn{7}{|l|}{ Husband's parents: } \\
\hline Father's occupational status ${ }^{3}$ & 0.038 & $(0.31)$ & 0.294 & $(1.95)$ & -0.120 & $(0.74)$ \\
\hline Financial problems in youth & -0.058 & $(1.33)$ & -0.061 & $(1.17)$ & -0.057 & $(1.07)$ \\
\hline Number of siblings of husband & -0.008 & $(0.99)$ & -0.008 & $(0.91)$ & 0.001 & $(0.10)$ \\
\hline Parental weath ${ }^{4}$ & $0.096 * *$ & $(5.08)$ & $0.070 * *$ & $(3.03)$ & $0.061 *$ & $(2.53)$ \\
\hline \multicolumn{7}{|l|}{ Wife's parents: } \\
\hline Father's occupational status ${ }^{3}$ & 0.078 & $(0.62)$ & 0.195 & $(1.30)$ & -0.184 & $(1.14)$ \\
\hline Financial problems in youth & -0.029 & $(0.63)$ & -0.038 & $(0.72)$ & -0.018 & $(0.32)$ \\
\hline Number of siblings of wife & $-0.022 * \star$ & $(2.75)$ & $-0.020 *$ & $(2.23)$ & -0.012 & $(1.28)$ \\
\hline Parental weath ${ }^{4}$ & $0.107 * \star$ & $(5.53)$ & $0.097 * *$ & $(4.02)$ & $0.074 * *$ & $(2.96)$ \\
\hline \multicolumn{7}{|l|}{ Respondent's characteristics: } \\
\hline Age of husband at marriage/cohabitation & & & & & 0.011 & $(1.95)$ \\
\hline Duration of the union & & & & & $0.109 * *$ & $(5.32)$ \\
\hline Duration squared (/100) & & & & & $-0.132 * \star$ & $(2.88)$ \\
\hline Married vs. cohabitating & & & & & $0.454 * *$ & $(4.94)$ \\
\hline Number in household & & & & & 0.018 & $(0.87)$ \\
\hline Husband's education & & & & & 0.007 & $(1.22)$ \\
\hline Wife's education & & & & & 0.007 & $(1.08)$ \\
\hline Household income (log) & & & & & $0.471 \star \star$ & $(10.50)$ \\
\hline $\begin{array}{l}\text { Log likelihood } \\
\mathrm{N}\end{array}$ & \multicolumn{2}{|c|}{$\begin{array}{c}-23312.2 \\
4471\end{array}$} & \multicolumn{2}{|c|}{$\begin{array}{l}-2277.1 \\
4471\end{array}$} & \multicolumn{2}{|c|}{$\begin{array}{l}-2151.1 \\
4471\end{array}$} \\
\hline
\end{tabular}

Source: Survey Actifs Financiers 1992

${ }^{1}$ Absolute values of t-statistics are in parentheses. The sample is restricted to respondents who were less than

age 65 at the time of the survey. Parental terms refer to period when respondent (spouse) "was young".

${ }^{2}$ Also included in the analysis are terms for city size and year of marriage.

${ }^{3}$ Occupational status coded by ISEI scores, divided by 100 (Ganzeboom, et. al. 1992).

${ }^{4}$ Four category scale. See text for details. 
Table 2. Parental Resource Effects on Home Value, Tobit estimates ${ }^{1}$

\begin{tabular}{|c|c|c|c|c|}
\hline Variables $^{2}$ & & & & \\
\hline & Coef. & t-value & Coef. & t-value \\
\hline Constant & $10.379 * *$ & $(17.77)$ & $-37.639 * *$ & $(12.04)$ \\
\hline Husband's parents: & & & & \\
\hline Father's occupational status ${ }^{3}$ & $2.056 *$ & $(2.48)$ & -0.580 & $(0.69)$ \\
\hline Financial problems in youth & -0.271 & $(0.95)$ & -0.220 & $(0.80)$ \\
\hline Number of siblings of husband & -0.057 & $(1.12)$ & 0.003 & $(0.07)$ \\
\hline Parental weath ${ }^{4}$ & $0.339 * *$ & $(2.71)$ & $0.245 *$ & $(2.02)$ \\
\hline Wife's parents: & & & & \\
\hline Father's occupational status ${ }^{3}$ & $1.845 *$ & $(2.22)$ & -0.437 & $(0.52)$ \\
\hline Financial problems in youth & -0.204 & $(0.69)$ & -0.101 & $(0.35)$ \\
\hline Number of siblings of wife & $-0.127 \star$ & $(2.50)$ & -0.074 & $(1.48)$ \\
\hline Parental weath ${ }^{4}$ & $0.496 * \star$ & $(3.85)$ & $0.363 * *$ & $(2.91)$ \\
\hline Respondent's characteristics: & & & & \\
\hline Age of husband at marriage/cohabitation & & & $0.071 *$ & $(2.35)$ \\
\hline Duration of the union & & & $0.711 * \star$ & $(6.51)$ \\
\hline Duration squared (/100) & & & $-0.994 * \star$ & $(4.23)$ \\
\hline Married vs. cohabitating & & & $3.740 * \star$ & $(6.83)$ \\
\hline Number in household & & & 0.127 & $(1.17)$ \\
\hline Husband's education & & & 0.054 & $(1.70)$ \\
\hline Wife's education & & & 0.053 & $(1.61)$ \\
\hline Household income (log) & & & $2.593 * \star$ & $(11.48)$ \\
\hline $\begin{array}{l}\text { Log likelihood } \\
\text { N }\end{array}$ & $\begin{array}{r}-11 \\
4\end{array}$ & & $\begin{array}{r}-11 \\
4\end{array}$ & \\
\hline
\end{tabular}

Source: Survey Actifs Financiers 1992

Dependent variable is log(home value). Absolute values of t-statistics are in parentheses. The sample is restricted to respondents who were less than age 65 at the time of the survey.

Parental terms refer to period when respondent (spouse) "was young".

${ }^{2}$ Also included in the analysis are terms for city size and year of marriage.

${ }^{3}$ Occupational status coded by ISEI scores, divided by 100 (Ganzeboom, et. al. 1992) .

${ }^{4}$ Four category scale. See text for details. 
Table 3. The Impact of Parental Transfers on Downpayment Proportion, Ordered Probit model ${ }^{1}$

\begin{tabular}{|c|c|c|c|c|}
\hline \multirow[t]{2}{*}{ Variables $^{2}$} & \multicolumn{2}{|c|}{ (1) } & \multicolumn{2}{|c|}{ (2) } \\
\hline & Coef & $\underline{t \text {-value }}$ & coef & t-value \\
\hline \multicolumn{5}{|l|}{ Characteristics of respondent: } \\
\hline Age of husband at marriage/cohabitation & $0.047 * \star$ & $(8.82)$ & $0.047 * \star$ & $(8.79)$ \\
\hline Duration of union at home purchase & $0.018 *$ & $(2.27)$ & $0.018 *$ & $(2.23)$ \\
\hline Duration squared (/100) & $0.097 * *$ & $(3.67)$ & $0.097 * *$ & $(3.67)$ \\
\hline Married vs. cohabiting & -0.080 & $(0.67)$ & -0.079 & $(0.66)$ \\
\hline Number in household & $-0.126 * \star$ & $(7.48)$ & $-0.126 * *$ & $(7.49)$ \\
\hline Husband's education & $0.020 * *$ & $(3.70)$ & $0.020 * *$ & $(3.65)$ \\
\hline Wife's education & $0.017 * *$ & $(3.29)$ & $0.017 * *$ & $(3.29)$ \\
\hline Husband's occupational status ${ }^{3}$ (/100) & $0.386 * *$ & $(2.67)$ & $0.386 * *$ & $(2.67)$ \\
\hline \multicolumn{5}{|l|}{ Transfers received: } \\
\hline Gift before home purchase & $0.153^{*}$ & $(2.32)$ & & \\
\hline Bequest before home purchase & $0.140 *$ & $(2.27)$ & & \\
\hline Gift after home purchase & 0.091 & $(1.55)$ & & \\
\hline Bequest after home purchase & -0.083 & $(1.61)$ & & \\
\hline Gift value before home purchase (log/100) & & & $1.325 *$ & $(2.30)$ \\
\hline Bequest value before home purchase (log/100) & & & $1.224 *$ & $(2.28)$ \\
\hline Gift value after home purchase (log/100) & & & 0.823 & $(1.63)$ \\
\hline Bequest value after home purchase (log/100) & & & -0.646 & $(1.46)$ \\
\hline Log likelihood & \multicolumn{2}{|c|}{-4982.4} & \multicolumn{2}{|c|}{-4982.1} \\
\hline $\mathrm{N}$ & \multicolumn{2}{|c|}{3271} & \multicolumn{2}{|c|}{3271} \\
\hline
\end{tabular}

* $\mathrm{p}<.05, \quad * * \mathrm{p}<.01$

Source: Survey Actifs Financiers 1992.

${ }^{1}$ Ordered Probit model for down payment proportion with six categories. Absolute values of $t-$ statistics are in parentheses. Dependent variable is log(home value). Terms for city size and year of home purchase were also included in the regression. Cut point parameters not shown. Sample is restricted to respondents who were living together at the time of the purchase and were less than 65 years old in the year of the survey.

2Also included in the analysis are terms for city size and year of home purchase.

${ }^{3}$ Occupational status coded by ISEI scores (Ganzeboom, et. al. 1992). 
Table 4. Estimates of the Parental Transfer Effect on Downpayment Proportion with Correction for Endogeneity Bias, Ordered Probit model ${ }^{1}$

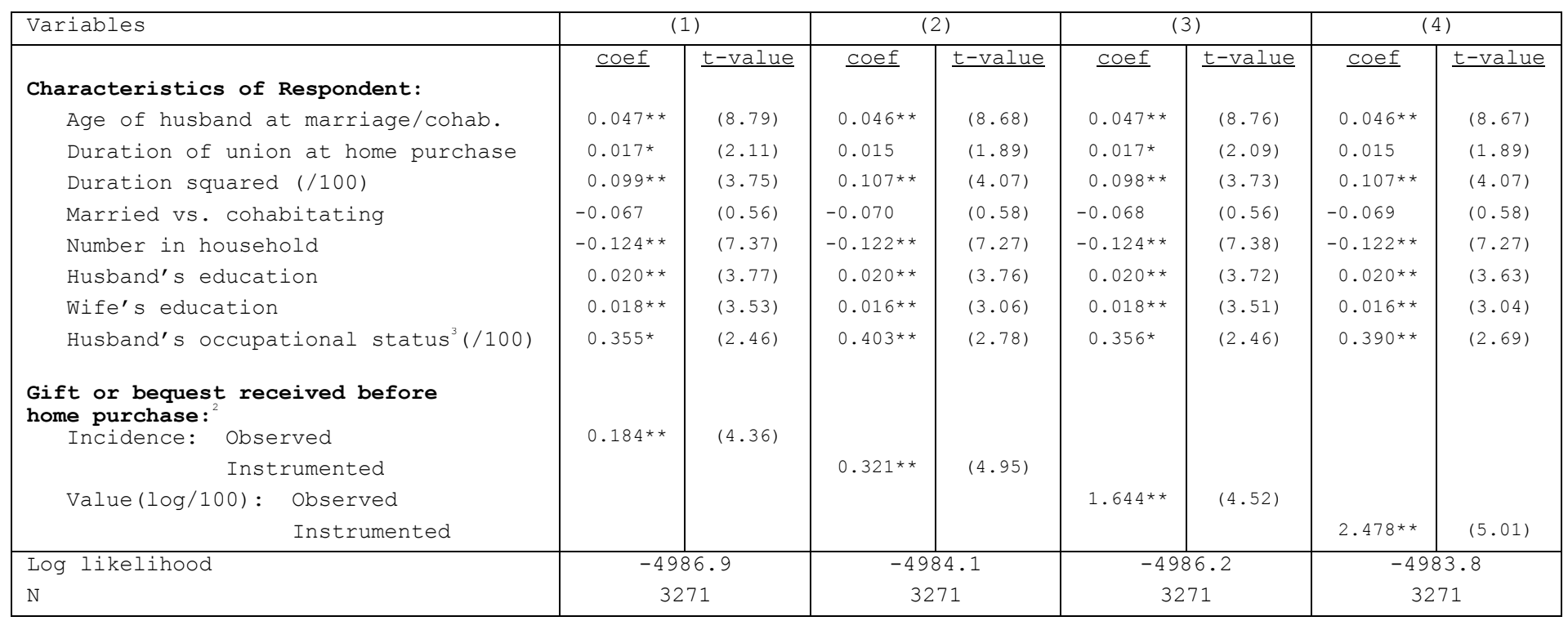

$\star \mathrm{p}<.05, \quad * \star \mathrm{p}<.01$

Source: Survey Actifs Financiers 1992.

${ }^{1}$ Ordered Probit model for down payment proportion with six categories. Absolute values of t-statistics are in parentheses. Also included in model are terms for city size and year of home purchase. Cut point parameters not shown. The sample is restricted to respondents who were living together at the time of home purchase and were less than age 65 at the time of the survey.

${ }^{2}$ The parental transfer variable is treated as exogenous in models (1) and (3). Instrumentation is from a Probit equation for incidence of transfer receipt in model (2), and from a Tobit model for the log value of transfer amount in model(4). Covariates in the instrumentation equations are father's occupational status, financial hardship in youth, parental wealth (these three variables respectively for husband's and wife's parents), and the variables in the second stage model.

${ }^{3}$ Occupational status coded by ISEI scores (Ganzeboom, et. al. 1992). 
Table 5. The Impact of Parental Transfers on Home Value, OLS Estimates ${ }^{1}$

\begin{tabular}{|c|c|c|c|c|}
\hline \multirow[t]{2}{*}{ Variables $^{2}$} & \multicolumn{2}{|c|}{ (1) } & \multicolumn{2}{|c|}{ (2) } \\
\hline & coef & $\underline{t \text {-value }}$ & $\underline{\text { coef }}$ & t-value \\
\hline Constant & $9.604 * *$ & $(36.04)$ & $9.612 * *$ & $(36.09)$ \\
\hline \multicolumn{5}{|l|}{ Characteristics of respondent: } \\
\hline Age of husband at marriage/cohab. (/100) & -0.079 & $(0.31)$ & -0.096 & $(0.38)$ \\
\hline Duration of the union & $0.030 * *$ & $(3.34)$ & $0.029 * *$ & $(3.33)$ \\
\hline Duration squared (/100) & $-0.068 * \star$ & $(3.54)$ & $-0.068 * *$ & $(3.54)$ \\
\hline Married vs. cohabitating & $0.175 * *$ & $(3.06)$ & $0.175 * *$ & $(3.07)$ \\
\hline Number in household (/100) & 0.428 & $(0.52)$ & 0.416 & $(0.50)$ \\
\hline Husband's education (/10) & $0.149 * *$ & $(6.31)$ & $0.147 * *$ & $(6.26)$ \\
\hline Wife's education (/10) & $0.075 * \star$ & $(3.11)$ & $0.075 * *$ & $(3.10)$ \\
\hline Household income (log) & $0.296 * *$ & $(15.56)$ & $0.295 * *$ & $(15.55)$ \\
\hline \multicolumn{5}{|l|}{ Transfers received: } \\
\hline Gift before home purchase & $0.105 * *$ & $(3.24)$ & & \\
\hline Bequest before home purchase & 0.023 & $(0.77)$ & & \\
\hline Gift after home purchase & -0.022 & $(0.77)$ & & \\
\hline Bequest after home purchase & 0.036 & $(1.39)$ & & \\
\hline Gift value before home purchase (log/100) & & & $0.938 * *$ & $(3.34)$ \\
\hline Bequest value before home purchase (log/100) & & & 0.232 & $(0.91)$ \\
\hline Gift value after home purchase (log/100) & & & -0.152 & $(0.63)$ \\
\hline Bequest value after home purchase (log/100) & & & 0.369 & $(1.68)$ \\
\hline $\mathrm{R}^{2}$ & \multicolumn{2}{|c|}{$\frac{1}{0.35}$} & \multicolumn{2}{|c|}{0.35} \\
\hline $\mathrm{N}$ & \multicolumn{2}{|c|}{2452} & \multicolumn{2}{|c|}{2452} \\
\hline
\end{tabular}

$* \mathrm{p}<.05, \quad * * \mathrm{p}<.01$

Source: Survey Actifs Financiers 1992.

${ }^{1}$ Home value (log) at time of the survey. Absolute values of t-statistics are in parentheses. The sample is restricted to respondents who were living together at the time of home purchase and were less than age 65 at the time of the survey.

${ }^{2}$ Terms for city size and year of marriage are included in the regressions. 
Table 6. Impact of Parental Transfers on Down Payment Proportion and Home Value, Joint Estimation Model $^{1}$

\begin{tabular}{|c|c|c|c|c|c|c|c|c|}
\hline \multirow[t]{3}{*}{ Variables $^{2}$} & \multirow{2}{*}{\multicolumn{2}{|c|}{$\begin{array}{c}\text { (1) } \\
\text { Downpayment }\end{array}$}} & \multicolumn{2}{|c|}{$\begin{array}{c}(2) \\
(2)\end{array}$} & \multicolumn{4}{|c|}{ (3) } \\
\hline & & & Home & alue & \multicolumn{4}{|c|}{ Downpayment \& home value } \\
\hline & coef & t-value & coef & $\underline{t \text {-value }}$ & $\underline{\text { Coef }}$ & t-value & coef & t-value \\
\hline Constant & & & $9.611 * \star$ & $(38.01)$ & & & $9.787 * \star$ & $(27.38)$ \\
\hline Age of husband at marriage/cohab. & $0.055 * *$ & $(8.92)$ & -0.001 & $(0.29)$ & $0.060 * *$ & $(8.28)$ & 0.001 & $(0.22)$ \\
\hline Duration of union at home purchase & $0.019 * *$ & $(2.07)$ & & & $0.017 *$ & $(1.69)$ & & \\
\hline Duration squared (/100) & $0.106 * *$ & $(3.50)$ & & & $0.123 * *$ & $(3.75)$ & & \\
\hline Duration of union at current time & & & $0.030 * *$ & $(3.19)$ & & & $0.029 * *$ & $(2.37)$ \\
\hline Duration squared (/100) & & & $-0.067 * *$ & $(3.69)$ & & & $-0.070 * *$ & $(3.01)$ \\
\hline Married vs. cohabitating & -0.088 & $(0.61)$ & $0.175 * *$ & $(2.69)$ & -0.105 & $(0.60)$ & 0.146 & $(1.53)$ \\
\hline Number in household & $-0.140 * *$ & $(7.81)$ & 0.004 & $(0.57)$ & $-0.155 * *$ & $(7.55)$ & -0.001 & $(0.06)$ \\
\hline Husband's education & $0.023 * *$ & $(3.86)$ & $0.015 * *$ & $(5.99)$ & $0.028 * *$ & $(4.19)$ & $0.016 * *$ & $(4.33)$ \\
\hline Wife's education & $0.023 * *$ & $(3.93)$ & $0.007 * \star$ & $(3.07)$ & $0.026 * *$ & $(3.92)$ & $0.009 * *$ & $(2.37)$ \\
\hline Husband's occupational status ${ }^{2}$ (/100) & $0.493 * *$ & $(2.94)$ & & & $0.382 * *$ & $(2.10)$ & & \\
\hline Household income (log) & & & $0.294 * *$ & $(16.97)$ & & & $0.277 * \star$ & $(11.28)$ \\
\hline $\begin{array}{c}\text { Gift or bequest amount received } \\
\text { before home purchase (log/100) }\end{array}$ & $2.045 * \star$ & $(4.67)$ & $0.683 * *$ & $(3.73)$ & $2.339 * \star$ & $(4.69)$ & $0.780 * *$ & $(2.93)$ \\
\hline \multicolumn{3}{|l|}{ Correlation between residuals (t-value) } & & & \multicolumn{4}{|c|}{$0.616 * * \quad(17.17)$} \\
\hline Log likelihood $-\mathrm{R}^{2}$ & \multirow{2}{*}{\multicolumn{2}{|c|}{$\begin{array}{c}-3542.37 \\
2452\end{array}$}} & \multirow{2}{*}{\multicolumn{2}{|c|}{$\begin{array}{c}-1383.71 \\
2452\end{array}$}} & \multicolumn{4}{|c|}{-5102.51} \\
\hline $\mathrm{N}$ & & & & & & & 52 & \\
\hline
\end{tabular}

$\star \mathrm{p}<.05, \quad \star * \mathrm{p}<.01$

Source: Survey Actifs Financiers 1992.

${ }^{1}$ Equation (1) is an Ordered Probit model for the down payment proportion with 6 categories. Equation (2) is an OLS regression for the housing value (in log), and (3) is a joint estimation by maximum likelihood of the Ordered Probit and OLS equations. The equations for downpayment proportion also include dummies for city size and year of home purchase; the equations for home value include dummies for city size and year of marriage. Absolute values of t-statistics are in parentheses.

${ }^{2}$ Occupational status coded by ISEI scores (Ganzeboom et. al. 1992). 
Table A-1. Descriptive statistics for the full sample

\begin{tabular}{|c|c|c|c|}
\hline Variables & Renters & Homeowners & Total \\
\hline \multicolumn{4}{|l|}{ Husband's parents: } \\
\hline Father's occupational status & 0.392 & 0.368 & 0.375 \\
\hline Financial problems in youth & 0.268 & 0.262 & 0.264 \\
\hline Number of siblings of husband & 3.007 & 2.950 & 2.968 \\
\hline Parental weath & 0.914 & 1.040 & 1.001 \\
\hline \multicolumn{4}{|l|}{ Wife's parents: } \\
\hline Father's occupational status ${ }^{3}$ & 0.393 & 0.370 & 0.377 \\
\hline Financial problems in youth & 0.242 & 0.230 & 0.234 \\
\hline Number of siblings of wife & 3.034 & 2.947 & 2.974 \\
\hline Parental weath ${ }^{4}$ & 0.834 & 0.998 & 0.948 \\
\hline \multicolumn{4}{|l|}{ Respondent's characteristics: } \\
\hline Age of husband at marriage/cohabitation & 25.034 & 24.616 & 24.744 \\
\hline Duration of the union & 13.446 & 20.651 & 18.453 \\
\hline Married vs. cohabitating & 0.805 & 0.970 & 0.920 \\
\hline Number in household & 3.441 & 3.654 & 3.589 \\
\hline Husband's education & 8.400 & 8.595 & 8.535 \\
\hline Wife's education & 8.104 & 8.105 & 8.105 \\
\hline Household income (log) & 11.782 & 12.030 & 11.955 \\
\hline \multicolumn{4}{|l|}{ Transfers received since marriage/cohab. } \\
\hline Incidence of receipt of a gift/bequest & 0.206 & 0.527 & 0.429 \\
\hline Value of the gift/bequest (log) & 2.119 & 5.241 & 4.289 \\
\hline Number of observations & 1364 & 3107 & 4471 \\
\hline
\end{tabular}

Source: Survey Actifs Financiers 1992. 
Table A-2. Descriptive statistics for the homeowners' sample

\begin{tabular}{|c|c|c|c|}
\hline Variables & $\begin{array}{c}\text { No receipt } \\
\text { of gift or } \\
\text { bequest } \\
\text { before home } \\
\text { purchase } \\
\text { (OK) }\end{array}$ & $\begin{array}{c}\text { Receipt of } \\
\text { gift and/or } \\
\text { bequest } \\
\text { before home } \\
\text { purchase } \\
\text { (OK) }\end{array}$ & $\begin{array}{c}\text { Total } \\
\text { homeowners }\end{array}$ \\
\hline \multicolumn{4}{|l|}{ Characteristics of respondent: } \\
\hline Age of husband at marriage/cohab. & 24.167 & 25.016 & 24.387 \\
\hline Duration of the union & 19.058 & 21.353 & 19.654 \\
\hline Married vs. cohabitating & 0.971 & 0.984 & 0.974 \\
\hline Number in household & 3.813 & 3.633 & 3.766 \\
\hline Husband's education & 8.785 & 8.958 & 8.830 \\
\hline Wife's education & 8.210 & 8.549 & 8.299 \\
\hline Husband's occupational status & 48.048 & 48.248 & 48.100 \\
\hline Household income (log) & 12.072 & 12.086 & 12.075 \\
\hline Home value (francs) ${ }^{1}$ & 701,628 & 782,323 & 722,592 \\
\hline \multicolumn{4}{|l|}{ Transfers received (Incidence): } \\
\hline Gift--before home purchase & 0.000 & 0.593 & 0.154 \\
\hline Bequest--before home purchase & 0.000 & 0.499 & 0.130 \\
\hline Gift--after home purchase & 0.109 & 0.535 & 0.219 \\
\hline Bequest--after home purchase & & & \\
\hline \multicolumn{4}{|l|}{ Transfers received (francs): } \\
\hline Gift--before home purchase & 0.000 & 81,294 & 21,119 \\
\hline Bequest--before home purchase & 0.000 & 86,354 & 22,433 \\
\hline Gift--after home purchase & 21,535 & 79,021 & 36,469 \\
\hline Bequest--after home purchase & 25,859 & 92,499 & 43,171 \\
\hline Number of observations & 1815 & 637 & 2452 \\
\hline
\end{tabular}

Source: Survey Actifs Financiers 1992. 